\title{
Isolation and Reactions of a Phosphorylated Form of Phosphoryl Transferase from Beef Heart Mitochondria ${ }^{1}$
}

\author{
ROBERT E. BEYER ${ }^{2}$ \\ Institute for Enzyme Research, University of Wisconsin, Madison, Wisconsin; and Laboratory of Chemical \\ Biology, Department of Zoology, The University of Michigan, Ann Arbor, Michigan 48104
}

Received October 24, 1967 ; accepted November 25, 1967

\begin{abstract}
Phosphoryl transferase, a mitochondrial protein which increases the phosphorylative capacity of poorly phosphorylating submitochondrial particles and catalyzes an ATP-ADP exchange reaction, is phosphorylated during oxidation either of succinate or pyruvate-malate. Inhibitors of oxidative phosphorylation and electron transfer, as well as uncouplers of oxidative phosphorylation, inhibit the phosphorylation of the transferase when phosphorylation is mediated by electron transfer. The protein is also phosphorylated by ATP, the donor group being specifically the terminal phosphate of ATP. The transphosphorylation reaction is not inhibited by inhibitors of electron transfer and coupled phosphorylation, nor by uncouplers of oxidative phosphorylation. The phosphoryl form of the transferase can phosphorylate ADP in the presence of hexokinase, glucose, and magnesium ion, but the transfer is only $50 \%$ complete. During this transfer reaction a portion of the protein-bound phosphate becomes transformed to an acid-stable form. Phosphorus is released from phosphoryl transferase as inorganic orthophosphate at $\mathrm{pH} 4$ and 10 and by heat, but is relatively stable at $\mathrm{pH} 7.5$ at $0^{\circ}$. Hydroxylamine also induces release of proteinbound phosphorus as inorganic phosphate. The possible role of the phosphoryl group of the transferase in oxidative phosphorylation is discussed.
\end{abstract}

In previous reports from this laboratory the isolation of a protein, phosphoryl transferase, from $\mathrm{HBHM}^{3}$ and ETPH $\left(\mathrm{Mg}^{2+}\right.$,

1 This research was supported in part by $\mathrm{Na}$ tional Institutes of Health grants AM 06751 MET and AM 10056 BI0 from the National Institute of Arthritis and Metabolic Diseases; Institutional Grant 94 to the University of Michigan from the National Science Foundation; American Cancer Society Institutional Grants (IN-40G and Project 94) to the University of Michigan Cancer Research Institute; and a Rackham Faculty Research Fellowship, the University of Michigan. Meat byproducts were generously furnished by Oscar Mayer and Co., Madison, Wisconsin.

2 The major portion of this research was performed while the author was the recipient of a Research Career Development Award (5-K3-GM4862) from the National Institute of Genoral Medical Science.

'Abbreviations used: HBHM, heavy beef heart mitochondria; ETPH $\left(\mathrm{Mg}^{2+}, \mathrm{Mn}^{2+}\right)$, phosphorylat-
$\left.\mathrm{Mn}^{2+}\right)$ has been described. Phosphoryl transferase increased the phosphorylative capacity of poorly phosphorylating submitochondrial particles, ETPH(EDTA-2), and appeared to function in one of the transfer steps in oxidative phosphorylation (1-3). This report describes the phosphoryl transferring reactions catalyzed by the transferase and the isolation of the enzyme in a phosphorylated form. The transfer reaction appears to involve formation of the phosphoryl enzyme as an intermediate. Some

ing submitochondrial particles from sonic extracts of HBHM; ETPH(EDTA-2), poorly phosphorylating submitochondrial particles from sonic extracts of HBHM; Dpm, disintegrations per minute; DEAE, diethylaminoethane; G-6-P, glucose 6phosphate; EDTA, ethylenediaminetetraacetate; DNP, 2,4-dinitrophenol; $\mathrm{F}_{3} \mathrm{CCP}, \quad p$-trifluoromethoxycarbonyl cyanidephenylhydrazone. 
of the experiments here reported have been the subject of a preliminary report (4).

\section{METHODS}

Submitochondrial particles, HBHM, and phosphoryl transferase were prepared as described previously (3). Carbamyl phosphate ( ${ }^{{ }^{\circ} \mathrm{P}} \mathrm{P}$-labeled) was synthesized according to a modification of the method of Metzenberg et al. (5) and was used as a substrate to synthesize $\gamma\left({ }^{32} \mathrm{P}\right) \mathrm{ATP}$ according to a modification ${ }^{4}$ of the method of Hokin and Hokin (6) that depends on carbamyl phosphokinase as the catalyst for transfer of phosphate from carbamylphosphate to ADP. Generous quantities of this enzyme, free of adenylate kinase, were supplied by Dr. Margaret Marshall. $\beta, \gamma\left({ }^{32} \mathrm{P}\right)$ ATP was obtained by using AMP as phosphate acceptor during oxidative phosphorylation catalyzed by $\mathrm{HBHM}$ in the presence of ${ }^{32} \mathrm{P}_{\mathrm{i}}$ with pyruvate-malate as substrate. Labeled ATP was purified from the reaction mixture by chromatography on DEAE-substituted cellulose and gradient elution with triethylammonium bicarbonate according to Smith and Khorana (7). Identification and purity of the products was established by paper chromatography in the Pabst system I (8). The amounts of $P_{i}$ and G-6-P were determined according to the isobutanolbenzene extraction method as described by Lindberg and Ernster (9). Occasionally, G-6-P was also determined directly by the chromatographic method of Bandurski and Axelrod (10), the authentic phosphate ester serving as carrier. Radinactive phosphorus was counted in a thinwindow, gas-flow counter or a low-background (less than 2 counts/minute) thin-window, gas-flow counter. Protein was estimated by a biuret procedure (11). All chemicals were of analytical reagent grade or equivalent.

Reagent sources were $\left.\alpha{ }^{(32} \mathrm{P}\right)$ A'TP, International Chemical and Nuclear Corp.; oligomycin, Wisconsin Alumnae Research Foundation; atractylate, kindly provided by Dr. Renato Santi; and $\mathrm{F}_{3} \mathrm{CCP}$, kindly provided by Dr. Peter Heytler.

\section{RESULTS}

Chromatography of phosphorylated mitochondrial protein. Preliminary experiments had indicated that mitochondrial proteins, after solubilization, could be phosphorylated when incubated with particles undergoing oxidative phosphorylation, and that a portion of the phosphorus in the protein fraction was released when the proteins were ex-

${ }^{4} \mathrm{~A}$. Worcel and L. Hokin, unpublished procedure. posed to $0.1 \mathrm{~N}$ acid at $100^{\circ}$ for 10 minutes. After separation of the soluble proteins from the particles, the extract was fractionated with ammonium sulfate before chromatography on DEAE-cellulose; the various fractions were examined for radioactivity (Fig. 1). The method of protein fractionation was that employed previously $(2,3)$ to isolate phosphoryl transferase. Prior to chromatography on DEAEcellulose, the ammonium sulfate fraction was divided into two equal parts. One part was treated with $\mathrm{ADP}, \mathrm{Mg}^{2+}$, hexokinase, and glucose in an effort to determine whether phosphoryl-protein was present and capable of phosphorylating ADP; the other part was not so treated.

The elution pattern of protein shown in Fig. 1 was typical of this step in the purification of phosphoryl transferase (3). The peak, eluted at approximately $90 \mathrm{ml}$, which in the routine preparation of the enzyme contains phosphoryl transferase $(2,3)$, also contained considerable radioactive phosphorus in the control sample. Prior treatment of the crude ammonium sulfate fraction with $\mathrm{ADP}, \mathrm{Mg}^{2+}$, hexokinase, and glucose resulted in an $87 \%$ reduction of the radioactivity of this peak and the appearance of considerable radioactivity in a peak appearing at $195 \mathrm{ml}$ in part A of Fig. 1. Paper chromatographic analysis of this latter peak indicated that the radioactivity cochromatographed with authentic G-6-P. This result suggested that this product of the reaction was adsorbed to protein during the final Sephadex treatment. The peak eluted at $200 \mathrm{ml}$ in the control fraction (Fig. 1, part B) did not co-chromatograph with G-6-P. This product has not been identified. It is also of considerable interest that the amount of radioactivity in the wash (eluted between 0 and $20 \mathrm{ml}$ ) was greatly diminished as a result of treatment with $\mathrm{ADP}, \mathrm{Mg}^{2+}$, glucose, and hexokinase. Also notable was the fact that the protein peak corresponding to phosphoryl transferase and the radioactivity peak $(80-95 \mathrm{ml})$ did not coincide; the radioactive compound was somewhat retarded during elution, a not surprising result if a portion of the protein contained in that peak was in a phospho- 


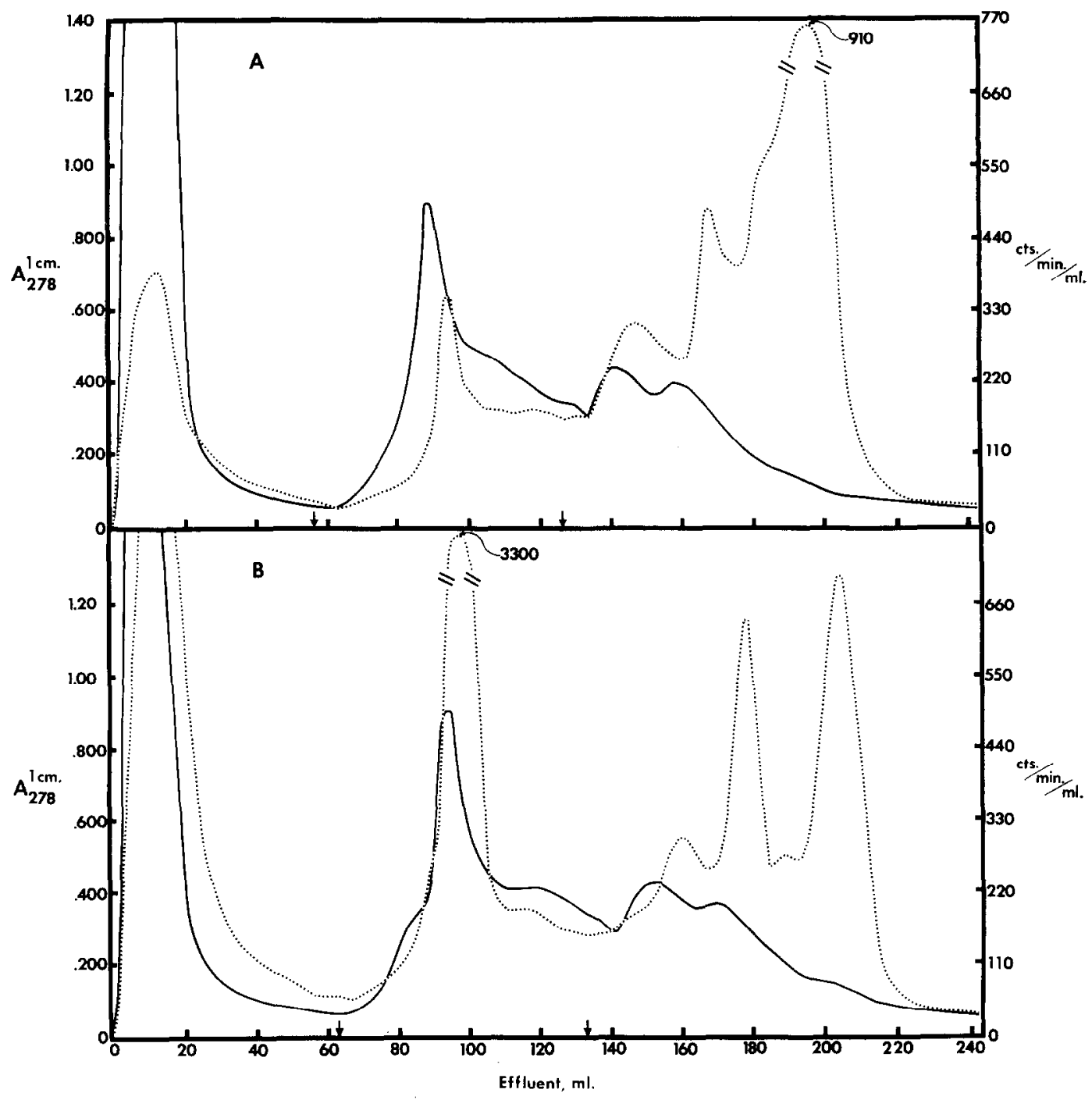

FIG. 1. Chromatography of ${ }^{2} \mathrm{P}$-labeled mitochondrial proteins. A suspension of HBHM $(195 \mathrm{ml}$ containing $30 \mathrm{mg}$ protein $/ \mathrm{ml}$ ) in a solution $0.15 \mathrm{M}$ in $\mathrm{KCl}$ and $0.01 \mathrm{M}$ in Tris-acetate, $\mathrm{pH} 7.5$, was treated with $20 \mathrm{ke}$ sound (Branson Sonifier, model S75, 7.5 A output, 60 seconds, sample cooled in a jacketed cell around which was circulated ethylene glycol at $-10^{\circ}$ ) in $40-$ $\mathrm{ml}$ portions. After sonic treatment the suspension was made $5 \mathrm{~mm}$ with respect to $\mathrm{MgCl}_{2}$ and $10 \mathrm{~mm}$ with respect to pyruvate and malate. The suspension was warmed to $30^{\circ}$, and 200 $\mu$ moles of ${ }^{32} \mathrm{P}_{\mathrm{i}}(1 \mathrm{mC} / 100 \mu$ moles $)$ was added. After 5 minutes of incubation at $30^{\circ}$ with the labeled phosphate, the suspension was made $10 \mathrm{~mm}$ with respect to EDTA, cooled, and spun at $105,000 \mathrm{~g}$ for 60 minutes. The supernatant solution was decanted carefully, adjusted to $45 \%$ saturation with ammonium sulfate, and maintained at ice temperature for 15 minutes before centrifuging at $35,000 \mathrm{~g}$ for 5 minutes. The pellet was discarded; the supernatant solution was brought to $70 \%$ saturation with ammonium sulfate and allowed to stand at $0^{\circ}$ for 15 minutes. The suspension was centrifuged at $35,000 \mathrm{~g}$ for 5 minutes, the pellet was dissolved in a minimal volume of cold $50 \mathrm{~mm}$ Tris-sulfate, $\mathrm{pH} 7.5$, and desalted on a $2 \times 20$-cm column of Sephadex G-25M previously equilibrated with $50 \mathrm{~mm}$ Tris-sulfate, $\mathrm{pH}$ 7.5. The yield of product was $286 \mathrm{mg}$ protein at a specific radioactivity of 2630 counts $/ \mathrm{minute} / \mathrm{mg}$. The resulting solution was divided into two equal parts, and to part A was added $71.5 \mu$ moles ADP, 71.5 $\mu$ moles $\mathrm{MgCl}_{2}, 143 \mu$ moles glucose, and $3.6 \mathrm{mg}$ crystalline hexokinase. A volume of water 
form. Indeed, Yankeelov et al. (12) have separated two proteins on cellulose, phosphoand dephospho-phosphoglucomutase, that differ by one phosphorus atom per molecule. Experiments similar to that reported in Fig. 1 have been performed (4) in which the transferase was incubated with particles oxidizing succinate in the presence of radioactive $P_{i}$ and rotenone to prevent reduction of NAD. The results of this experiment were qualitatively the same as in the experiment described above. It is also of interest that ATP is eluted in this type of chromatographic system as a fairly broad fraction with a peak at approximately $160 \mathrm{ml}$.

Effect of inhibitors on phosphorylation of phosphoryl transferase. A series of experiments was undertaken to study the effects of known inhibitors of electron transfer and oxidative phosphorylation, and uncouplers of oxidative phosphorylation, on the phosphorylation of phosphoryl transferase during the oxidation of suecinate. Because of the apparent labile nature of the link between the phosphorus and residues of the phorphorylated protein, the isolation procedure was shortened by using stepwise elution of the DEAE-substituted cellulose columns instead of the more lengthy multiple gradient elution. Uncouplers of oxidative phosphorylation, such as DNP and $\mathrm{F}_{3} \mathrm{CCP}$, severely inhibited the incorporation of radiophosphate into phosphoryl transferase at stage $\mathrm{C}$ in the purification procedure (see Ref. 3 for steps in the preparation of the enzyme) (Table I). The transferase was incubated with particles undergoing oxidation in the presence of succinate and in the absence of exogenous ADP as phosphate acceptor. Oligomycin, an inhibitor of oxidative phosphorylation (13), also severely inhibited the incorporation of radiophosphate into phosphoryl transferase, as did antimycin $A$, an inhibitor of electron transfer. The deletion of substrate (succinate) also resulted in a lower proteinbound phosphate content in the fraction isolated from DEAE-substituted cellulose, but such values obtained in the absence of succinate were considerably higher than those obtained in the presence of inhibitors and uncouplers. The higher values may have been due to exchange acitivity or to the presence of endogenous substrate. Considerably higher blank (no substrate) values were obtained in the absence of rotenone, presumably because of endogenous substrates that are predominantly of the type which reduced NAD in the eitric acid cycle (14)

Transfer of protein-bound phosphorus to $A D P$. It was of interest to determine whether the phosphorus bound to phosphoryl transferase (see above for conditions) could be transferred to $\mathrm{ADP}$ to form ATP. This possibility appeared likely since it had been observed that the transferase catalyzed an exchange of phosphate hetween ADP and ATP (15). Consequently, labeled phosphoryl transferase, stage $\mathrm{C}$, was prepared as described in Table I, but at a higher specific radioactivity. The labeled protein was incubated with an acceptor system consisting of $\mathrm{ADP}, \mathrm{Mg}^{2+}$, hexokinase, and glucose in order to ensure that the equilibrium of the reaction would favor the transfer of a phosphoryl group to ADP (Table II). Approximately $60 \%$ of the phosphorus bound to phosphoryl transferase was capable of being transferred to glucuse. Although the data in Table II represent the result of a typical experiment of this type,

equal to these additions was added to part B. Parts A and B were incubated at $30^{\circ}$ for 5 minutes, cooled rapidly, and each passed through a column $(1.5 \times 20 \mathrm{~cm})$ of Sephadex $\mathrm{G}-25 \mathrm{M}$ previously equilibrated with $5 \mathrm{~mm}$ Tris-sulfate, $\mathrm{pH} 7.5$. The two protein-containing eluants were applied to $1 \times 10$-cm DEAE-substituted cellulose columns and washed with $5 \mathrm{~mm}$ Tris-sulfate, $\mathrm{pH} 7.5$. Fractions of $3.5 \mathrm{ml}$ were collected in a fraction collector equipped with drop counters. A linear gradient, applied at the first arrow, was constructed with $150 \mathrm{ml}$ $5 \mathrm{~mm}$ Tris-sulfate in the mixing chamber and $150 \mathrm{ml} 150 \mathrm{~mm}$ Tris-sulfate in the reservoir chamber. At the second arrow both chambers were emptied and the mixing chamber was filled with $150 \mathrm{ml}$ of $150 \mathrm{~mm}$ Tris-sulfate and the reservoir chamber with $350 \mathrm{~mm}$ Tris-sulfate. The absorbancy at $278 \mathrm{~m} \mu$ (1-cm path) was measured and the radioactivity of each fraction was determined. 
TABLE I

Phosphorylation of Stage C Phosphoryl Transferase by Mitochondria Oxidizing Succinate in the Presence of $P_{i}$

HBHM were treated and incubated as described under Fig. 1 except that rotenone $\left(10^{-6} \mathrm{M}\right)$ was present during incubation of the particles with substrate (succinate, $10 \mathrm{~mm}$ ) and inorganic phosphate $(1 \mathrm{~mm})$. Inhibitors and uncouplers were added prior to substrate and ${ }^{32} \mathrm{P}_{\mathbf{i}}$ at the following final concentrations: DNP, $5 \times 10^{-5} \mathrm{M} ; \mathrm{F}_{3} \mathrm{CCP}$, $5 \times 10^{-7} \mathrm{M}$; oligomyein, $0.5 \mu \mathrm{g} / \mathrm{ml}$; and antimycin A, $1 \mu \mathrm{g} / \mathrm{mg}$ protein. Treatment after incubation with substrate was the same as described in the legend for Fig. 1 except that DEAE-substituted cellulose columns of $20 \times 100 \mathrm{~mm}$ werc used for chromatography of the incubated protein fraction and gradient elution was not used. After the protein fractions were applied, the column was washed with cold $5 \mathrm{~mm}$ Tris-sulfate, $\mathrm{pH} 7.5$, until the $A_{278}^{1 \mathrm{~cm}}$ fell to below 0.05 . Phosphoryl transferase stage $\mathrm{C}$ was eluted with $0.1 \mathrm{~m}$ Tris-sulfate, $\mathrm{pH}$ 7.5 , and protein and radioactivity were determined. The background of the counter used in this experiment was 21 counts/minute and was subtracted from each radioactive assay. The complete system contained sonic-treated HBHM $(20 \mathrm{ml}, 30 \mathrm{mg}$ protein $/ \mathrm{ml}), \mathrm{KCl}(0.15 \mathrm{M})$, Trisacetate, $\mathrm{pH} 7.5(0.01 \mathrm{M}), \mathrm{MgCl}_{2}(5 \mathrm{mM})$, succinate $(10 \mathrm{~mm}),{ }^{32} \mathrm{P}_{\mathrm{i}}\left(1 \mathrm{~mm}, 2.05 \times 10^{6}\right.$ counts $/ \mu$ mole $)$, and rotenone $\left(10^{-6} \mathrm{M}\right)$.

\begin{tabular}{lc}
\hline \multicolumn{1}{c}{ System } & $\begin{array}{c}\text { Protein-bound } 22 \mathrm{P} \\
\text { (counts/minute/mg protein) }\end{array}$ \\
\hline Complete & 7840 \\
+ DNP & 426 \\
+ F FCP $_{\text {O }}$ & 391 \\
+ Oligomycin & 567 \\
+ Antimycin A & 1377 \\
- Succinate & 1894 \\
\hline
\end{tabular}

values as low as $46 \%$ for the transfer of radiophosphate from labeled protein to glucose have been observed. Of further interest in the complete system (Table II) was the distribution of the remainder of the label. Approximately $20-25 \%$ of the label originally associated with the protein was recovered in an acid-stable form, while between 5 and $10 \%$ was recovered as inorganic orthophosphate. Oligomycin did not affect significantly the extent of transfer. Atractylate and DNP were also without effect. The transfer to glucose required the
TABLE II

Transfer of Bound 32P From Phosphoryl

${ }^{32} \mathrm{P}-\mathrm{L}$ abeled phosphoryl transferase (stage C) was prepared as described in Table I except that the specific radioactivity of the $P_{i}$ was $4 \times 10^{6}$ counts/minute $/ \mu$ mole. Each complete reaction tube contained, in $1 \mathrm{ml}, 2.4 \mathrm{mg}$ of phosphoryl transferase protein with a relative specific radioactivity of 12,940 counts/minute/mg; $50 \mu$ moles Tris-sulfate, $\mathrm{pH} 7.5 ; 5 \mu$ moles $\mathrm{MgCl}_{2} ; 20 \mu$ moles glucose; $10 \mu$ moles ADP; and $0.25 \mathrm{mg}$ crystalline hexokinase. When present the following compounds were added prior to $\mathrm{ADP}$ at the following concentrations: oligomycin, $0.5 \mu \mathrm{g} / \mathrm{ml}$; potassium atractylate, $5 \mathrm{~m} \mu$ moles $/ \mathrm{mg}$ protcin; DNP, $5 \times$ $10^{-5} \mathrm{M} ; \mathrm{P}_{\mathrm{i}}, 5 \mathrm{~mm}$. The reaction was initiated by the addition of ADP and was allowed to proceed for 10 minutes at $30^{\circ}$. The reaction was terminated by the addition of $2 \mathrm{ml}$ of silicotungstic acid $(1 \mathrm{~N}$ with respect to $\mathrm{H}_{2} \mathrm{SO}_{4}$ ) prepared according to (9). The mixture was placed in a boiling water bath for 10 minutes under a condenser to avoid loss of fluid volume, and cooled to room temperature. Three $\mathrm{ml}$ of a 1:1 mixture of isobutanol-benzene and $0.5 \mathrm{ml}$ of $10 \%$ ammonium molybdate were added, and the mixture was shaken for 30 seconds. The isobutanol-benzene layer was removed and the aqueous layer was reextracted with $3 \mathrm{ml}$ of water-saturated isobutanol-benzene. The isobutanol-benzene layers were combined and both layers were counted. In addition, the protein precipitale was collected from the aqueous phase, washed twice with silicotungstic acid, dissolved in $6 \mathrm{~N} \mathrm{KOH}$, and counted. The aqueous layer was checked occasionally for G-6-P by paper chromatography according to Bandurski and Axelrod (10). Radioactivity in the isobutanol-benzene layer was considered to represent inorganic orthophosphate, that in the aqueous layer, G-6-P, and that in the protein precipitale, acidstable protein-bound phosphate. Within the limits of our technique, no other labeled compounds were observed in the aqueous layer.

\begin{tabular}{|c|c|c|c|c|}
\hline \multirow{2}{*}{ System } & \multicolumn{3}{|c|}{ Counts/minute/ $2.4 \mathrm{mg}$ protein } & \multirow{2}{*}{$\begin{array}{l}\text { Counts } \\
\text { recovered } \\
(\%)\end{array}$} \\
\hline & G-6-P & $P_{1}$ & Protein & \\
\hline Complete & 18,944 & 2484 & 6832 & 91 \\
\hline + Oligomycin & 18,012 & 3106 & 8075 & 91 \\
\hline+ Atractylate & 20,497 & 1242 & 6832 & 90 \\
\hline$+\mathrm{DNP}$ & 16,770 & 3416 & 6211 & 85 \\
\hline$+\mathrm{P}_{\mathrm{i}}$ & 19,114 & 2171 & 6444 & 89 \\
\hline$-\mathrm{ADP}$ & 621 & 25,466 & 1242 & 88 \\
\hline$-\mathrm{Mg}^{2+}$ & 58 & 26,708 & 272 & 87 \\
\hline
\end{tabular}


presence both of ADP and $\mathrm{Mg}^{2+}$. The ADP requirement for formation of G-6-P establishes ATP as an intermediate in the transfer and excludes the possibility that preformed ATP adsorbed to the transferase could account for formation of G-6-P.

\section{TABLE III}

Phosphorylation of Phosphoryl Trangferase BY $\gamma\left({ }^{32} \mathrm{P}\right) \mathrm{ATP}$

Stage D phosphoryl transferase was prepared as described in Refs. 2 and 3, concentrated to 7.7 $\mathrm{mg}$ protein/ml with Carbowax 6000, and dialyzed against $50 \mathrm{~mm}$ Tris-sulfate, $\mathrm{pH}$ 7.5. For phosphoryl transfer from ATP to enzyme the reaction mixture, in $1 \mathrm{ml}$, contained Tris-sulfate, $\mathrm{pH} 7.5$ (200 $\mu$ moles $) ; \mathrm{MgCl}_{2}$ (5 $\mu$ moles), $\gamma\left({ }^{32} \mathrm{P}\right) \mathrm{ATP} \quad(0.590$ $\mu$ mole of specific activity $16.2 \times 10^{6}$ counts/ minute $/ \mu$ mole), and stage $D$ phosphoryl transferase $(5 \mathrm{mg})$. The reaction was initiated by the addition of enzyme and was allowed to proceed for 5 minutes at $30^{\circ}$. The tube was cooled rapidly and the contents were applied to a Sephadex G-25M column $(15 \times 200 \mathrm{~mm})$ previously equilibrated with $50 \mathrm{~mm}$ Tris-sulfate, $\mathrm{pH} 7.5$. The size of the Sephadex column was adequate for separation of protein from ATP; the separation of the two was checked by the absorption at 260 and $278 \mathrm{~m} \mu$ in the eluates. The protein fraction was collected. Transfer of radiophosphate from protein to ADP was achieved under the following conditions: To each of two test tubes was added, in the order listed; ${ }^{22} \mathrm{P}$-labeled phosphoryl transferase (2.4 $\mathrm{mg})$, hexokinase $(0.25 \mathrm{mg})$, glucose $(20 \mu$ moles $)$, $\mathrm{ADP}(10 \mu$ moles $)$ to tube $\mathrm{A}$ only, and $\mathrm{MgCl}_{2}$ (10 $\mu$ moles), and the mixture was brought to a final volume of $1.95 \mathrm{ml}$. Both tubes were incubated at $30^{\circ}$ for 10 minutes and the reaction was terminated by the addition of $4 \mathrm{ml}$ of silicotungstic acid which was $1 \mathrm{~N}$ with respect to $\mathrm{H}_{2} \mathrm{SO}_{4}$. The tubes were incubated in a boiling water bath for 10 minutes under a condenser to avoid evaporation and cooled, and the contents were centrifuged. $\mathrm{G}-6-{ }^{32} \mathrm{P},{ }^{32} \mathrm{P} i$, and ${ }^{32} \mathrm{P}$-protein were assayed as described in Table II.

\begin{tabular}{|c|c|c|c|}
\hline Reaction & \multicolumn{3}{|c|}{ Counts/minute/mg protein } \\
\hline $\begin{array}{l}\gamma\left({ }^{32} \mathrm{P}\right) \mathrm{ATP}+\text { protein } \mathrm{Mg}^{2+} \\
\mathrm{ADP}+\text { protein-32P }\end{array}$ & \multicolumn{3}{|c|}{6408} \\
\hline \multirow{2}{*}{ Transfer reaction } & \multicolumn{3}{|c|}{ Total counts/minute in } \\
\hline & G-6-P & $\mathrm{Pi}$ & Protein \\
\hline Protein-32P to glucose & 4928 & 5405 & 5667 \\
\hline $\begin{array}{l}\text { Protein- }{ }^{32} \mathrm{P} \text { to glucose } \\
\text { minus ADP }\end{array}$ & 210 & 14853 & 937 \\
\hline
\end{tabular}

(This latter point has been explored in a direct manner and is reported below.) The distribution of radiophosphate after incubation of the transferase in the absence of ADP or $\mathrm{Mg}^{2+}$ differed considerably from that in the complete system (Table II). Essentially all of the phosphorus assaycd as $P_{i}$ after exposure of the transferase for 10 minutes at $100^{\circ}$ in $1 \mathrm{~N}$ acid. Since data derived from control experiments indicated that less than $15 \%$ of the phosphorus was released as $\mathrm{P}_{\mathbf{i}}$ after exposure of the protein to $30^{\circ}$ for 10 minutes (see also Table VII), it would appear that the bulk of the proteinbound phosphorus was stable in the absence of $\mathrm{Mg}^{2+}$ or ADP. The presence of $5 \mathrm{~mm}$ $P_{i}$ did not alter the final distribution of the label in the complete system, indicating that the protein-bound phosphorus was not in equilibrium with inorganic phosphate and did not in any way exchange with external inorganic phosphate during the transfer reaction.

Phosphorylation of phosphoryl transferase by ATP. Since phosphoryl transferase catalyses an ATP-ADP exchange reaction (15), the reversibility of the transfer reaction could be anticipated, namely, the phosphorylation of phosphoryl transferase by ATP. Initial experiments were performed with stage $\mathrm{C}$ enzyme that has been reported $(2,3)$ to be approximately $85-90 \%$ pure. However, the data in Table III were obtained with stage $D$ enzyme, which was homogenous in the analytical untracentrifuge and which appeared as a single component when examined by molecular gel filtration (3). Forty nmoles of the enzyme [if a molecular weight of 124,000 is assumed for phosphoryl transferase (see Ref. 3)] was incubated with the labeled ATP. If each molecule of the enzyme had contained one phosphoryl group upon reisolation after incubation with labeled ATP, $6.48 \times 10^{6}$ counts should have been recovered in the protein fraction. The data in Table III for the reaction $\gamma\left({ }^{32} \mathrm{P}\right) \mathrm{ATP}+$ protein $\rightarrow$ $\mathrm{ADP}+$ protein- $^{32 \mathrm{P}}$ show that approximately $0.5 \%$ of this amount of radioactivity was recovered bound to the protein, indicating that the equilibrium of the reaction must lie far to the left, i.e., toward the 
formation of ATP from the labeled protein, despite the initial high concentration of ATP relative to protein in the reaction mixture. The data in the lower portion of Table III, indicating that the phosphoryl group of the transferase can be transferred to glucose via ADP as intermediate phosphoryl acceptor, thus demonstrate the complete reversibility of the reaction. Of the approximately 16,000 counts/minute/mg enzyme in the assay tube, $30.8 \%$ appeared as $\mathrm{G}-6{ }^{32} \mathrm{P}$.

Another question of considerable concern was the form of the phosphorus bound to the enzyme. The experiments in Table II and III indirectly suggested that either the bound form was not ATP, or if it was ATP, it was in a form not accessible to hexokinase. A preliminary experiment comparing the transfer of label from $8-\left({ }^{14} \mathrm{C}\right) \mathrm{ATP}$ and $\gamma\left({ }^{32} \mathrm{P}\right) \mathrm{A}$ TP to enzyme (1) indicated that the purine portion of ATP was not bound to the enzyme. However, this type of experiment was susceptible to the criticism that the specific activities of the two ATP samples

\section{TABLE IV}

Transfer of Label from $\alpha, \gamma$, AND $\beta, \gamma\left({ }^{32} \mathrm{P}\right)$ ATP to Phosphoryl Transherase

The three species of labeled ATP were obtained as described in Methods. After dilution of labeled ATP with carrier ATP, the specific radioactivities of each of the three species of labeled ATP were as follows: $\gamma\left({ }^{32} \mathrm{P}\right) \mathrm{ATP}, 19.3 \times 10^{6} ; \alpha\left({ }^{32} \mathrm{P}\right) \mathrm{ATP}$, $20 \times 10^{6} ;$ and $\beta, \gamma\left({ }^{32} \mathrm{P}\right) \mathrm{ATP}, 22.6 \times 10^{6}$. The comparisons were made in two separate experiments on different days for technical reasons and are so indicated below. Each incubation tube contained, in $0.7 \mathrm{ml}, 35 \mu$ moles Tris-sulfate, $\mathrm{pH}$ $7.5 ; 2 \mu$ moles ATP; $5 \mu$ moles $\mathrm{MgCl}_{2}$; and $1.25 \mathrm{mg}$ of stage $\mathrm{D}$ phosphoryl transferase. The reaction was initiated by the addition of enzyme and was maintained at $30^{\circ}$ for 5 minutes. Transfer of label from ATP to protein was assayed as described in Table III.

\begin{tabular}{ccc}
\hline Experiment & ATP & $\begin{array}{c}\text { Counts/minute/1.25 } \\
\text { mg protein }\end{array}$ \\
\hline 1 & $\alpha\left({ }^{32} \mathrm{P}\right)$ & 13 \\
& $\gamma\left({ }^{32} \mathrm{P}\right)$ & 2078 \\
& & \\
2 & $\gamma\left({ }^{32} \mathrm{P}\right)$ & 2214 \\
& $\beta, \gamma\left({ }^{32} \mathrm{P}\right)$ & 1066 \\
\hline
\end{tabular}

TABLE V

Phosphorus Content of Phosphoryl Transferase

Stage $C$ phosphoryl transferase was extensively dialyzed against $50 \mathrm{~mm}$ Tris-sulfate, $\mathrm{pH}$ 7.5 , and analyzed for phosphorus by the micromethod of Chen et al. (16). An equal volume of the fluid external to the dialysis sac was used as blank. Analyses were kindly performed in the laboratory of Dr. Sidney Fleisher. The lower limt of this technique is $0.15 \mu \mathrm{g}$ phosphorus per assay.

\begin{tabular}{ccc}
\hline $\begin{array}{c}\text { Phosphoryl } \\
\text { transferase (mg) }\end{array}$ & Phosphorus (ug) & $\begin{array}{c}\text { Phosphorus } \\
(\mu \mathrm{g}) / \mathrm{mg}\end{array}$ \\
\hline 1 & $<0.15$ & $<0.07$ \\
2 & 0.16 & 0.08 \\
4 & 0.29 & 0.07 \\
4 & 0.29 & 0.07 \\
\hline
\end{tabular}

were not similar and the counting methods were not the same. Consequently, two experiments, the results of which appear in Table IV, were performed in which the transfer of radiophosphate from ATP labeled in the $\gamma$, the $\alpha$, and the $\beta$ and $\gamma$ positions and of comparable specific radioactivities was measured.

The data from experiment 1 (Table IV) clearly showed that the $\alpha$-phosphate of ATP could not serve as a source of proteinbound phosphate. On the presumed basis of one mole of phosphorus bound per mole of enzyme, and a molecular weight of 124,000 for phosphoryl transferase (3), it was estimated that $1 \%$ of the enzyme molecules were labeled in this parlicular preparalion. The data from experiment 2 (Table IV) revealed that counts originating from doubly labeled ATP were approximately half of the counts originating from $\gamma\left({ }^{32} \mathrm{P}\right) \mathrm{ATP}$. Since the two samples of ATP in this experiment were of essentially equal specific radioactivities, and the terminal phosphate group of the doubly labeled ATP had one-half the specific activity of the singly labeled $A T P$ the difference in amount of label originating from the doubly labeled ATP clearly indicated that the transfer reaction involved only the $\gamma$ position of ATP.

Phosphorus content of phosphoryl transferase. The finding that phosphoryl transferase could be converted to a phosphoform 
prompted an analysis of the phosphorus content of the protein. Based on a molecular weight of 124,000 for phosphoryl transferase (3), the data in Table $V$ would indi-

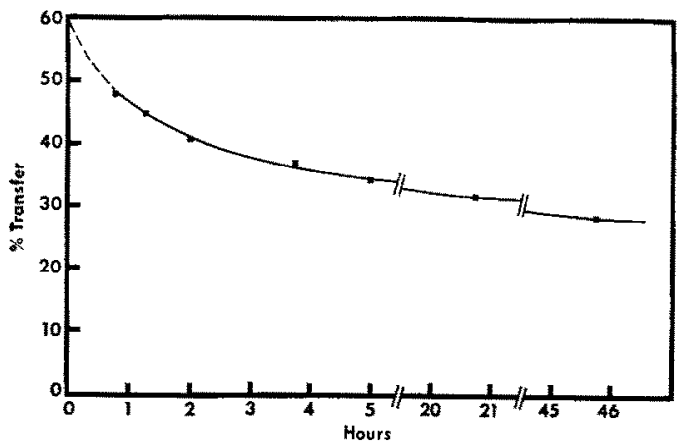

Fic. 2. Loss of phosphoryl transferase activity with time. The phosphorylated form of stage $C$ phosphoryl transferase was prepared as described in Table III and maintained at $\mathrm{p} I \mathrm{7} .5$ and $0^{\circ}$. The product contained 4618 counts $/$ minute $/ \mathrm{mg}$. One$\mathrm{ml}$ portions (containing $2 \mathrm{mg}$ protein) were removed the times indicated in the figure, and the transfer of ${ }^{32} \mathrm{P}$ to $\mathrm{ADP}$ was measured as described in Table III. The data are expressed as the percentage of the counts in the original phosphophosphoryl transferase transferred to glucose, via ADP, to form G-6-P. The data were corrected for radio decay of ${ }^{2} \mathrm{P}$. The broken line represents extrapolation to zero time.

\section{TABLE VI}

\section{EFFUCT OF PH ON THE STABILTY OF Protein -Bound ${ }^{32} \mathrm{P}$}

Phosphorylated stage C phosphoryl transferase was prepared as described in the caption of Table III. The specifio activity was 1175 counts/minute $/ \mathrm{mg}$ protein. The solutions, in $50 \mathrm{~mm}$ Trissulfate, $\mathrm{pH} 7.5$, were divided into three portions of $1 \mathrm{ml}$, each containing $1 \mathrm{mg}$ protein. The adjustments of $\mathrm{pH}$, monitored with a glass electrode, were made with either $2 \mathrm{~N} \mathrm{KOH}$ or $\mathrm{H}_{2} \mathrm{SO}_{4}$. The control sample received approximately equal volumes of a solution of $\mathrm{KOH}$ adjusted to $\mathrm{pH}$ 7.5 with $\mathrm{H}_{2} \mathrm{SO}_{4}$. The neutralized samples were passed through 15 $\times 200-$ mu Sephadex G-25M columns previously equilibrated with $50 \mathrm{~mm}$ Tris-sulfate, $\mathrm{pH} 7.5$; the protein fraction was collected and the content of ${ }^{32} \mathrm{P}$ was analyzed.

\begin{tabular}{cc}
\hline Treatment & Counts/minute/mg protein \\
\hline pH 7.5 & 992 \\
pH 4.0 & 77 \\
pH 10.0 & 104 \\
\hline
\end{tabular}

\section{TABLE VII}

Temperature Stamilty of the Phosphate Moiety of 32 P-Labeled Phosphoryt,

Transferase

${ }^{32} \mathrm{P}-\mathrm{Phosphoryl}$ transferase was prepared from $\gamma\left({ }^{2} \mathrm{P}\right) \mathrm{ATP}$ as described in the caption of Table III. The activity of the product was $7167 \mathrm{dis}$ integrations/minute/(dpm)/mg. Radioactivity in this experiment was assayed in a Packard three-channel liquid scintillation counter with automatic external standardization. All samples were corrected for quenching. Aqueous samples were counted in the seintillation mixture of Gordon and Wolfe (18), which contains $4 \%$ CabO-Sil. Each sample contained $0.6 \mathrm{mg}{ }^{32} \mathrm{P}$-phosphoryl transferase, $4 \mu$ moles $\mathrm{MgCl}_{2}$, and $20 \mu$ moles Tris-sulfate, p $\mathrm{H} 7.5$, in a volume of $0.56 \mathrm{ml}$. After the experimental period the samples were cooled rapidly in ice and the hexokinase trapping system was added. The transfer reaction to glucose via ADP was accomplished as described in the caption of Table III. The fractions corresponding to ${ }^{32} \mathrm{P}_{\mathrm{i}}$ and $\mathrm{G}-6{ }^{32} \mathrm{P}$ were counted.

\begin{tabular}{|c|c|c|c|c|c|}
\hline \multirow{2}{*}{$\begin{array}{c}\text { Temper- } \\
\text { ature at } \\
\text { wbich } \\
\text { exposed } \\
\text { for } 10 \\
\text { min }\left({ }^{\circ} \mathrm{C}\right)\end{array}$} & \multirow[b]{2}{*}{ Total dpm } & \multicolumn{2}{|c|}{$P_{1}$} & \multicolumn{2}{|c|}{$\mathrm{G}-6-\mathrm{P}$} \\
\hline & & $\mathrm{dpm}$ & $\%$ & $\mathrm{dpm}$ & $\%$ \\
\hline 0 & 2105 & 840 & 39.9 & 1265 & 60.1 \\
\hline 15 & 2200 & 900 & 40.9 & 1300 & 59.1 \\
\hline 30 & 2242 & 967 & 43.1 & 1275 & 56.9 \\
\hline 45 & 3277 & 2633 & 80.3 & 644 & 19.7 \\
\hline 60 & 4088 & 3996 & 97.8 & 92 & 2.3 \\
\hline
\end{tabular}

eate that the enzyme preparation contained 0.25 mole of phosphorus per mole of enzyme. The enzyme did not appear to be a conventional phosphoprotein in that it did not contain, upon isolation, one or more phosphorus atoms per molecule of enzyme, nor did it appear to contain phospholipid.

Stability of the phosphoryl group associated with phosphophosphoryl transferase. The transfer of a phosphoryl group from the transferase to ADP was not affected severely by storage of the enzyme at $0^{\circ}$ (Fig. 2). The transfer was still $50 \%$ of the original level after almost 2 days of storage in ice. On the other hand, the effect of $\mathrm{pH}$ on the retention of labeled phosphorus by the enzyme was profound (Table VI), After the enzyme was exposed to $\mathrm{pH} 4$ for 30 minutes only $6.6 \%$ of the original counts was still bound to the protein as compared 
with $84.4 \%$ in the $\mathrm{pH} 7.5$ sample, and the sample maintained for the same amount of time at $\mathrm{pH} 10.0$ contained $8.9 \%$ of its original complement of ${ }^{32} \mathrm{P}$.

To determine whether incubation of the labeled protein did not by itself result in a disruption of the bond between protcin and phosphoryl group, the effect of prior treatment of phosphorylated phosphoryl transferase for 10 minutes at each of five different temperatures on the transfer of proteinbound ${ }^{32} \mathrm{P}$ to glucose via ADP was measured (Table VII). When the phosphorylated protein was maintained for 10 minutes at temperatures between $0^{\circ}$ and $30^{\circ}$, the transfer of the phosphoryl group to glucose via ADP was affected to a negligible degree. However, after incubation of the enzyme for the same length of time at $45^{\circ}$ and $60^{\circ}$ the subsequent transfer reaction was affected profoundly. In addition, a considerable proportion of the phosphorus appeared to have been released as $\mathrm{P}_{\mathbf{i}}$ prior to incubation of the protein with the hexokinase trapping system. This release accounts for the increase in the total radioactivity recovered in the latter two samples.

Hydroxylamine and protein-bound ${ }^{32} P$. In

\section{TABLE VIII}

EFFECT OF $\mathrm{NH}_{2} \mathrm{OH}$ ON THE RELEASE OF Protein-Bound ${ }^{32} \mathrm{P}$

Phosphorylated phosphoryl transferase was prepared as described in the caption of Table III. The relative specific radioactivity of the product was 2070 counts/minute/mg protein. During incubation at $30^{\circ}$, each sample contained $2.33 \mathrm{mg}$ phosphophosphoryl transferase, either $0.25 \mathrm{M} \mathrm{NH}_{2} \mathrm{OH}$ (salt-free) or an equivalent volume of water, and $0.1 \mathrm{M}$ Tris-sulfate, $\mathrm{pH} \mathrm{7.5.} \mathrm{The} \mathrm{initial}$ period of incubation with $\mathrm{NH}_{2} \mathrm{OH}$ was terminated by the addition of the hexokinase trapping system as described in the caption of Table III. Fractions corresponding to $\mathbf{P}_{\mathrm{i}}, \mathrm{G}-6-\mathrm{P}$, and protein were collected and counted.

\begin{tabular}{lcccrr}
\hline \multirow{2}{*}{ System } & $\begin{array}{c}\text { Time } \\
\text { at } 30^{\circ} \\
\text { (min) }\end{array}$ & \multicolumn{3}{c}{ Total counts/minute in } \\
\hline Control & 60 & 316 & 1758 & $2143(50.9)$ \\
$0.25 \mathrm{M} \mathrm{NH}_{2} \mathrm{OH}$ & 30 & 274 & 3234 & $1260(26.4)$ \\
$0.25 \mathrm{M} \mathrm{NH}_{2} \mathrm{OH}$ & 60 & 298 & 2942 & $754(18.9)$ \\
\hline
\end{tabular}

${ }^{a}$ Refers to the percentage of the recovered counts in $G-6-P$. an attempt to gain information on the type of attachment between the protein and its bound phosphorus, the effect of exposure of the transferase in its phosphorylated form to salt-free hydroxylamine was studied (Table VIII). After the enzyme was incubated for 30 minutes at $30^{\circ}$ with hydroxylamine, there was a reduction of $48.2 \%$ in the amount of protein-bound ${ }^{32} \mathrm{P}$ transferred to glucose via ADP. Incubation for a period of 60 minutes with hydroxylamine resulted in a reduction of $63 \%$ in the amount transferred by comparison with the untreated control sample. The amount of radiophosphate bound to the enzyme in an acidstable form was not severely altered by treatment with hydroxylamine, whereas the same treatment increased the phosphorus assaying as $\mathrm{P}_{\mathrm{i}}$ by $167 \%$.

\section{DISCUSSION}

The conventional formulation (20) of the sequence of events in oxidative phosphorylation has for some years embodied the explicit assumption of a phosphorylated intermediate in the synthesis of ATP, namely,

$$
\begin{aligned}
\mathrm{AH}_{2}+\mathrm{B}+\mathrm{I} & \rightarrow \mathrm{A} \sim \mathrm{I}+\mathrm{BH}_{2} \\
\mathrm{~A} \sim \mathrm{I}+\mathrm{X} & \rightarrow \mathrm{A}+\mathrm{X} \sim \mathrm{I} \\
\mathrm{X} \sim \mathrm{I}+\mathrm{P} & \rightarrow \mathrm{X} \sim \mathrm{P}+\mathrm{I} \\
\mathrm{X} \sim \mathrm{P}+\mathrm{ADP} & \rightarrow \mathrm{X}+\mathrm{ATP}
\end{aligned}
$$

Sum: $\mathrm{AH}_{2}+\bar{B}+\mathrm{P}_{\mathbf{i}}+\mathrm{ADP} \rightarrow \mathrm{A}+\mathrm{BH}_{2}+\mathrm{ATP}$

On the other hand, the elusive character of such intermediates of oxidative phosphorylation has led to a hypothesis which does not require the participation of a stable phosphorylated intermediate in oxidative phosphorylation (21). Several lines of evidence are consistent with the participation of phosphoryl transferase in oxidative phosphorylation: (a) the increase in the phosphorylative capacity of poorly phosphorylating submitochondrial particles by the transferase (3), (b) its ADP-ATP exchange activity (15), (c) the rapid phosphorylation of the protein during oxidative phosphorylation (19), (d) inhibition of the phosphorylation of the protein during oxidative phosphorylation by uncouplers and inhibitors of oxidative phosphorylation and by inhibitors of clectron transfer $(1,19)$, 
(e) the transfer of a phosphoryl group from the phosphorylated protein to $\mathrm{ADP}$, and (f) phosphorylation of the enzyme by the terminal phosphoryl group of ATP. The existence of a stable phosphorylated intermediate of oxidative phosphorylation has been postulated by Ter Welle and Slater (22) on the basis that the uncoupling of oxidative phosphorylation by arsenate can be reversed by $\mathrm{P}_{i}$. These authors have inferred that such evidence affords "perhaps the best evidence that a stable $X \sim P$ can be formed during respiratory-chain oxidative phosphorylation" (22).

$\Lambda$ altcrnative explanation for the phosphorylation of phosphoryl transferase during oxidative phosphorylation is that this protein would serve as an acceptor of a phosphoryl group originating from ATP formed during oxidative phosphorylation, and, in that case, would not serve as an intermediate in the synthesis of ATP. The fact that oligomycin inhibited the formation of the phosphorylated protein during oxidative phosphorylation does not constitute decisive evidence that the phosphorylated protein preceded the formation of ATP, i.e., does not allow a distinction between

$$
\begin{aligned}
& \mathrm{P}_{\mathrm{i}} \stackrel{\text { oligo }}{\longrightarrow} \sim \mathrm{P} \rightarrow \mathrm{ATP} \\
& \mathrm{P}_{\mathrm{i}} \stackrel{\text { olig. }}{\longrightarrow} \mathrm{ATP} \rightarrow \sim \mathrm{P} .
\end{aligned}
$$

Our present evidence does not permit us to distinguish between these alternatives. However, in the event that the latter alternative proves correct, phosphoryl transferase would be engaged in the transfer of a phosphoryl group from endogenous, bound ATP, to exogenous ADP. The finding by Heldt et al. (23) that endogenous ADP serves as an early phosphate acceptor during oxidative phosphorylation is consistent with such an interpretation.

The formation of a phosphorylated intermediate is in no way unique to phosphoryl transferase. $\mathrm{Na}^{+}+\mathrm{K}^{+}-$activated ATPase has been shown to form a phosphorylated intermediate (24-28) which appears to have the characteristics of an acyl phosphate (25-27). Phosphoglucomutase has been shown (12) to exist either in a phosphoor dephospho-enzyme form, as has alkaline phosphatase from Escherichia coli $(29,30)$.
Succinate thiokinase from mitochondria has been found to form kinetically active intermediates which contain phosphohistidine (31) and enzyme-bound succinyl phosphate (32), respectively. In addition, phosphoproteins are known to be formed rapidly during clectron transfer in yeast respiratory particles (33) and in chloroplasts (34). The latter work (34) is of particular interest since the phosphorus bound to chloroplast proteins did not appear to be either proteinbound phosphohistidine or phosphoserine (34). Although we do not pretend that this list represents a complete survey of possible phosphorylated intermediates, it is safe to say that such phenomena are far from being numerically restricted. Of particular relevance to the protein under discussion here, however, is the recent report (35) of the isolation from beef heart mitochondria of a phosphorylated intermediate involved in the ATP-ADP exchange reaction since some of its characteristics appear to be similar to those of phosphoryl transferase in its phosphorylated form. Both proteins catalyze an exchange between ATP and ADP, both are phosphorylated by $\gamma\left({ }^{32} \mathrm{P}\right) \mathrm{ATP}$, in both bound phosphate does not equilibrate with ${ }^{32} \mathrm{P}_{\mathrm{i}}$, and the phosphoryl group in both proteins is unstable outside a limited range of temperature and $\mathrm{pH}$. Also of interest in this regard is the report by Wadkins and Lehninger (36) that an ATP-ADP exchange enzyme isolated from rat liver mitochondria can increase the phosphorylative capacity of mitochondria depleted of this enzyme. The similarities between our preparation and those of Colomb et al., and Wadkins and Lehninger, are quite clear and suggest that the same enzyme is common to all three preparations.

The nature of the binding between phosphorus and protein deserves some mention since considerable difference was found between the stability of the phosphate residue before and after reaction of the ADP. Prior to reaction of the enzyme with ADP the protein-bound phosphorus was easily released by high $\mathrm{pH}$, heat, or acid. After the transfer of phosphate from the protein to ADP, a considerable portion of the phosphorus had been altered, resulting in a stable 
relationship such as that found in phosphorylserine. It is not unlikely that reaction of the transferase with ADP results in a conformational change in the enzyme which uncovers a serine side chain capable of forming a stable $O$-phosphoryl derivative. The $\mathrm{pH}$ lability of the bond prior to reaction with ADP would appear to argue against the phosphate residue being in the form of phosphorylhistidine, while the effect of hydroxylamine in releasing bound phosphate from the transferase suggests a carboxylphosphoryl linkage.

\section{ACKNOWLEDGMENTS}

The author expresses his gratitude to Professor David E. Green for advice, eneouragement, and laboratory facilities during the course of most of these investigations, to Mr. Earl Fronk for skilled technical assistance, and to Mrs. Janet MacDonald for help in the preparation of the manuscript. Technical advice from Dr. Charalambos Coutsogeorgopoulos concerning nucleotide chromatography is gratefully acknowledged.

\section{REFERENCES}

1. BEYER, R. E., Biochem. Biophys. Res. Commun. 16, 460 (1964).

2. Beyer, R. E., in "Methods in Enzymology," Vol. X ("Oxidation and Phosphorylation"; R. W. Estabrook and M. E. Pullman, eds.), p. 186 Academic Press, New York (1967).

3. BEYER, R. E., Arch Biochem. Biophys. 123, 41 (1968).

4. Beyer, R. E., Biochem. Biophys. Res. Commun. 17, 184 (1964).

5. Metzenberg, R. L., Marshall, M., and Conen, P. P., in "Biochemical Preparations" (H. A. Lardy, ed.), Vol. 7, p. 23. Wiley, New York (1960).

6. Hokin, M. R., and Hokin, L. E., J. Biol. Chem. 234, 1381 (1959).

7. Smith, M., and Khorana, H. G., Methods Enzymol. 6, 645 (1963).

8. Pabst Laboratories Circular OR-10, 1956, p. 20.

9. Lindberg, O., and Ernster, L., Methods Biochem. Anal. 3, 1 (1956).

10. Bandurski, R. S., and Axelrod, B., J. Biol. Chem. 193, 405 (1951).

11. GorNall, A. G., Bardawill, C. J., AND Da vid, M. M., J. Biol. Chem. 177, 751 (1949).

12. Yankeelov, J. A., JR., Horton, H. K., AND Koshland, D. E., JR., Biochemistry 3, 349 (1964).

13. LaRdy, H. A., Johnson, D)., And McMurray,
W. C., Arch. Biochem. Biophys. 78, 587 (1958).

14. Otson, M. S., and Von Korfa, R. W., J. Biol. Chem. 242, 325 (1967).

15. Beyer, R. E., Biochem. Biophys. Res. Commun. 17, 764 (1964).

16. Chen, P. S., JR., Toribara, T. Y., and Warner, H., Anal. Chem. 28, 1756 (1956).

17. Beinert, H., Green, D. E., Hele, P., Hift, H., Von Korff, R. W., and Ramakrishnan, C. V., J. Biol. Chem. 203, 35 (1953).

18. Gordon, C. F., and Wolfe, A. L., Anal. Chem. 32, 574 (1960).

19. Kвмр, Jr., A., in "Regulation of Metabolic Processes in Mitochondria" (J. M. Tager, S. Papa, E. Quagliariello, and E. G. Slater, eds.), B. B. A. Library, Vol. 7, p. 264. Elsevier, Amsterdam (1966).

20. Slater, E. C., Rev. Pure Appl. Chem. 8, 221 (1958).

21. Mitcheld, P., Biol. Rev. 41, 445 (1966).

22. Ter Welle, H. F., and Slater, E. C., Biochim. Biophys. Acta 89, 385 (1964).

23. Held T, H. W., JACOBS, H., AND KLINGen Berg, M., Biochem. Biophys. Res. Commun. 18, 174 (1965).

24. Post, R. L., Sen, A. K., and Rosenthal, A. S., J. Biol. Chem. 240, 1437 (1965).

25. Hokin, L. E., Sas'rRy, P. S., Galsworthy, P. R., And Yoda, A., Proc. Natl. Acad. Sci. U.S. 54, 177 (1965).

26. Nagano, K., Kanazawa, T., Mizuno, N., Tashima, Y., Nakao, T., and Nakao, M., Biochem. Biophys. Res. Commun. 19, 759 (1965).

27. Chigneli, C. F., and Titus, E., Proc. Natl. Acad. Sci. U.S. 56, 1620 (1966).

28. Blostein, R., Biochem. Biophys. Res. Commun. 24, 598 (1966).

29. Engstrom, L., and Åghen, G., Acla Chem. Scand. 12, 357 (1958).

30. Fernley, H. N., and Walker, P. G., Nature 212, 1435 (1966).

31. Mitchell, R. A., Butler, L. G., and Boyer, P. D., Biochem. Biophys. Res. Commun. 16, 545 (1964).

32. Nishimura, J. S., And Meister, A., Biochemistry 4, 1457 (1965).

33. Pinn.1, L. A., Lorini, M., Moret, V., and Siliprandi, N., Biochim. Biophys. Acta 97, 398 (1965).

34. Hinkson, J. W., and Boyer, P. D., Arch. Biochem. Biophys. 110, 16 (1965).

35. Colomr, M. G., Laturaze, J. G., and Vignais, P. V., Biochem. Biophys. Res. Commun. 24, 909 (1966).

36. Wadkins, C. L., ANd Lehninger, A. L., Federation Proc. 22, 1092 (1963). 